\title{
Socioeconomic factors determining ecosystem services local perceptions in two ecological zones in Benin (West Africa)
}

\author{
Fiacre Codjo AHONONGA ${ }^{1 *}$, Gérard Nounagnon GOUWAKINNOU ${ }^{1}$, \\ Samadori Sorotori Honoré BIAOU ${ }^{1}$, Séverin BIAOU ${ }^{1}$ and Roland Christel SONOUNAMETO ${ }^{2}$ \\ ${ }^{1}$ Laboratory of Ecology, Botany and Plant Biology, University of Parakou 03 BP 125 Parakou (Benin). \\ ${ }^{2}$ Laboratoire de Biomathématiques et d'Estimations Forestières, Faculté des Sciences Agronomiques, \\ Université d'Abomey-Calavi 04 BP 1525 Cotonou (Bénin). \\ ${ }^{*}$ Corresponding author; E-mail: fiacreahononga@gmail.com
}

\begin{abstract}
Forests have been undergoing diverse threats due to human activities and these may affect their role as Ecosystem Services (ES) providers. Therefore, it becomes crucial to undertake some analysis of the current socio-economic context of ES offerings to provide valuable information for the decision-making process and policy regarding sustainable forest management. This study aimed at highlighting the local perception of ES in two contrasting ecological regions. 689 respondents distributed in six districts were interviewed through a semistructured survey on the various ES and their assessment. The analysis in principal components is used to understand socio-cultural group perception. Then, we used Beta regression to know how socio-economic factors influence the rate of people knowledge of ES. Our results show that provisioning services were more overall perceived, followed by cultural services and regulating services. Youth perceived less regulating and supporting services. Furthermore, cultural services were the most perceived by the seniors. The perception of provisioning and regulating services is influenced respectively by education level and the poverty index. Taking into account the local perception of the different actors and the factors in the decision-making, local development can be improved in compliance with the objectives of biodiversity conservation.
\end{abstract}

(C) 2020 International Formulae Group. All rights reserved.

Keywords: Local perceptions, Ecosystem Services, environmental education, forest management, Benin Republic.

\section{INTRODUCTION}

Forest ecosystems together with human communities living around are facing increasing pressure worldwide (Parrotta et al., 2016). Deforestation, one of the main causes, disrupts its well-functioning through the loss of biodiversity and thus leads to a decline of ES (Kaboré et al., 2015) such as carbon sink (Gouwakinnou et al., 2018; Houghton and Hackler, 2006), soil formation (Sheng et al.,
2015) and food security (Dossou, 2004). Anthropogenic pressures, such as land use, affect biodiversity conservation efforts (Clerici et al., 2007) and the ES (Bidegain et al., 2019; Rodríguez-echeverry et al., 2018; Wilson et al., 2016). Several approaches have been initiated in order to tackle this challenge of loss of biodiversity and ES. One of them highlights the link between biodiversity conservation and ES provision. This approach was the result of the 
United Nations Convention on Biodiversity held in 1992, followed by the Millennium Ecosystem Assessments (MEA) in 2005. MEA defines the concept of ES as the benefits that humans enjoy directly or indirectly from the well-functioning of the ecosystem (MEA, 2005). The ratification of this concept has led to its increasing integration into political decision-making relating to the sustainable management and planning of ecosystems (TEEB, 2010). Recently, this provoked an enthusiasm of scientists on the subject to establish the relationship between biodiversity and ecosystem functioning, however with much controversy (Wardle and Zackrisson, 2005). In summing up their studies about the same subject, Costanza et al. (2007) found that a loss of $1 \%$ of biodiversity reduces by half the value of the ES provided by a given ecosystem. The goodness of the local and urban population (Naidoo et al., 2011) is therefore indisputable. The local communities that are near to forests ecosystem and tight to use the ecosystem forest' goods and services for their sustenance (Moutouama et al., 2019) are the most vulnerable when these ecosystems are malfunctioning. The economic importance and direct benefit that society enjoy from ecosystems for their well-being have been the subject of recent studies (Angelsen et al., 2014; Belcher et al., 2015; Ahammad et al., 2019).

However, understanding the socioeconomic and demographic drivers and the importance of ES are critical (Ouko et al., 2018; Ahammad et al., 2019; Gouwakinnou et al., 2019; Moutouama et al., 2019). Several studies have reported the importance of the social dimension to highlight the value of ES (Scholte et al., 2015; Iniguez-gallardo et al., 2018; Quintas-soriano et al., 2018; Yang et al., 2018). Yet, this social dimension is weakly associated with indirect services though they all contribute to the maintenance of the agricultural system while supporting economic incomes. Similarly, (Cuni-Sanchez et al., 2017) reports that the social science approach in addition to economics and ecology can help to assess ES and to ensure their best estimation. Knowledge, being a factor that influences the aptitudes and the behaviors of people, it helps to ensure behavioral conformity to management and policies (Ilboudo et al., 2020; Asah et al., 2014) of conservation (Vodouhê et al., 2010). According to Urgenson et al. (2013), understanding the local perception of ES in different contexts is an effective way, to realize the opportunities but also the difficulties that the landscape management is facing. This will help to implement targeted sustainable management strategies to improve the abilities of poor people to help to sustainable conservation to well-enjoy vital ecosystem services (Zhang et al., 2015).

Considering the importance of local perception of ES in ecosystem management, studies in Sub Saharan Africa have more focused on specific habitats including mountain ecosystems (Moutouama et al., 2019), forests reserve (Gouwakinnou et al., 2019; Ouko et al., 2018) though the landscape is in increasing degradation with the different types of land use (Biaou et al., 2019). This difference could affect strategies and policies of management if these do not take into account the different perceptions in the different zones to consider the specifications of each community. This is to implement strategies and policies adopted to their situation and maintain their long-term livelihood.

As in sub-Saharan countries, the forest cover is threatened in the Benin Republic, because the vegetation increasingly undergoing multiple pressures due to agriculture, breeding, logging, urbanization (Hountondji, 2008; Avakoudjo et al., 2014; Biaou et al., 2019; Biga et al., 2020). This study was undertaken to help to implement targeted sustainable management strategies to improve the ability of poor people to obtain vital ecosystem services.

\section{MATERIALS AND METHODS \\ Study area}

The study took place in Benin Republic in the administrative villages of the Sudanian zone $\left(9^{\circ} 45 \mathrm{~N}\right.$ and $12^{\circ} 25 \mathrm{~N}$, rainfall varies from 900 to $1100 \mathrm{~mm} /$ year) and the SudanoGuinean zone $\left(7^{\circ} 30^{\prime} \mathrm{N}\right.$ and $9^{\circ} 45^{\prime} \mathrm{N}$, rainfall varies from $900 \mathrm{~mm}$ to $1110 \mathrm{~mm} /$ year) (Figure 1). The Sudano-Guinean zone is dominated by 
mosaics open forests, likely with dense dry forests, dotted with trees and shrub savannas, and crossed by forest galleries (White, 1983). On the other hand, climatic vegetation of which shrubby savannas and mosaics of farm and fallow and some islets of open forests and wooded savannas (White, 1983) dominate the Sudanian zone. The major trends observed in terms of population growth in some localities in these areas could be the result of an important internal migration (INSAE, 2016). To this is added slash-and-burn farming almost exclusively rain-fed, transhumance, and the exploitation of timber. These activities encroach on the national forest cover from year to year. It gives birth to anthropized ecosystems going from wooded parks to fallows and impacts biodiversity (Sambiéni et al., 2015; Vodouhê et al., 2010) (Figure 1). These areas show a diversity of ethnic groups with different cultural practices.

\section{Site selection and sampling}

The study was conducted in two ecological zones. In each zone, three districts were randomly chosen. Six districts namely, Matéri, Toucountouna and Ségbana in Sudanese zone; Parakou Ouaké, and Dassa in Soudano-Guinean zone (Table 2) were considered. Thus $25 \%$ of the administrative villages of each district were chosen based on their closeness to forest reserves (Table 1). To define the representative size of the population to be interviewed, the proportion of individuals in each district that benefit from ES and belonging to the primary sector (farming, fishing, hunting, breeding, logging) (Table 1) was noted in the document from INSAE (2016). The size of the sample of people to be interviewed in each village was estimated using the formula proposed by Dagnelie (1998):

$N=U_{1-\alpha / 2}^{2} \frac{P i(1-P i)}{\delta^{2}}$

$\mathrm{Pi}$ : proportion of individuals belonging to the primary sector of each district and who benefit from ecosystems. U1- $\alpha / 2=1.96$, the value of the normal random variable for a risk $\alpha$ equal to 0.05 . The expected margin of error $\delta$ is $7 \%$. Thus, the number of respondents estimated by district is distributed proportionally in the villages. To ensure the proper distribution of the number of respondents per village, the size has been increased in certain villages. 689 individuals were considered and distributed in 66 villages. In each village, the individuals interviewed were chosen randomly and ranked according to their activities and their membership of a sociocultural group. The sample consists only of 18 and over old people. (Table 2). Table 2 shows the demographic characteristics of the individuals sampled in this study.

\section{Data collection}

The interviews were carried out from 20 February to 8 April 2019. This study was based on primary data from surveys and data from secondary sources. The secondary data related to socio-economic factors, also including the poverty index. They were collected from official documents published online (Cahier des villages et quartier de Ville du Bénin). The primary data collection through a semistructured questionnaire was used for data collection related to socio-demographic characteristics (age, gender, ethnicity) and socio-economic (education level, main activity) as well as the possession or not of a private plantation (Yes / No). Qualitative data about the perception of ES are also taken into account. After mentioning the services provided by forest ecosystems, each respondent expressed the importance $(1=$ Not important, $2=$ Important and $3=$ very important $)$, the satisfaction level $(0=$ Not satisfied, $1=$ Not very satisfied, $2=$ Very satisfied) as well as the trend of service provision over the past 10 years $(1=$ Low, $2=$ Intact, 3 = Improvement). The surveys were carried out in the local language when needed. Local field workers were trained on the concept of ecosystem services to limit the ES misinterpretation mentioned by the respondents. The ES mentioned were associated with the list of MEA services listed by Swinton and Zhang (2005) and used by Gouwakinnou et al. (2019). The services listed by Zhang are 29 grouped into three categories adapted from the MEA categories (Table 3). 
Open question options were intentionally included to get the services not mentioned by Swinton and Zhang (2005).

\section{Data analysis}

The collected data were processed through a descriptive analysis that consisted of determining the frequency of the citation of the ES, the importance, the trend, and the level of satisfaction by climate zones. The perception rate for each category of ES was estimated. The relationship between the number of services cited and the area, on the one hand, and the sex or gender on the other were assessed by the Chi-2 independence test. A Principal Component Analysis was carried out to assess the correlation between the perception of social sciences and the socio-cultural category. Also, to assess the factors influencing local perception, beta regression was used (CribariNeto and Zeileis, 2010). The poverty index, gender, age category (young people $(<30$ years), adults ( $30 \leq$ age $\leq 60)$ and the elderly (age> 60)) (Mensah et al., 2017), education level and the possession or not of a private plantation were considered as explanatory variables. The identification rate for each service category was considered as the response variable. Statistical analyses were performed using $\mathrm{R}$ software version 3.5.0.( $\mathrm{R}$ Core Team, 2018).

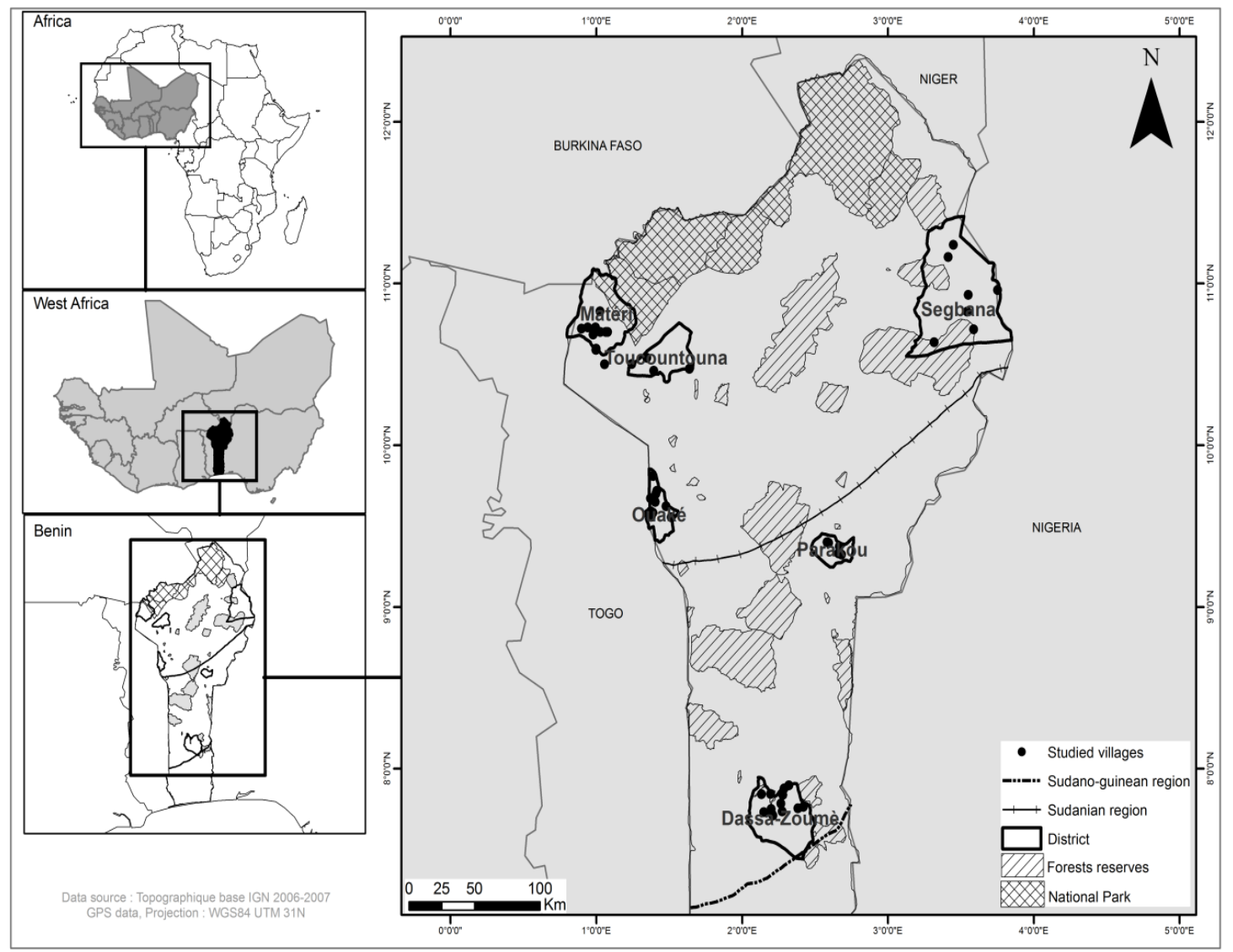

Figure 1: Location of the study zone and districts sampled. 
Table 1: Characteristics of the survey sampling.

\begin{tabular}{lcccc}
\hline Districts & $\begin{array}{c}\text { Pi } \\
(\boldsymbol{\%})\end{array}$ & $\begin{array}{c}\text { Total number of } \\
\text { villages }\end{array}$ & $\begin{array}{c}\text { Number of } \\
\text { villages }\end{array}$ & $\begin{array}{c}\text { Number of investigated } \\
\text { people }\end{array}$ \\
\hline Ouaké & 67.8 & 44 & 11 & 176 \\
Matéri & 88.4 & 56 & 14 & 98 \\
Dassa & 63.5 & 69 & 17 & 174 \\
Parakou & 11.8 & 42 & 11 & 88 \\
Toucountouna & 86.9 & 22 & 6 & 90 \\
Ségbana & 92 & 29 & 7 & 63 \\
\hline Total & & 262 & 66 & 689 \\
\hline \multicolumn{2}{r}{$(\mathrm{n}=689)$} & & &
\end{tabular}

Table 2: Demographic characteristic of respondents according to the ecological region.

\begin{tabular}{|c|c|c|c|}
\hline Categories & & Sudanian & Sudanese-Guinean \\
\hline \multirow{14}{*}{ Socio-cultural groups } & Other & 25 & 17 \\
\hline & Bariba & 1 & 51 \\
\hline & Biali & 64 & 8 \\
\hline & Boo & 33 & 0 \\
\hline & Ditamari & 15 & 1 \\
\hline & Fon & 0 & 60 \\
\hline & Foudou & 0 & 15 \\
\hline & Idaatcha & 0 & 118 \\
\hline & Kabiè & 0 & 15 \\
\hline & Lokpa & 0 & 138 \\
\hline & Nateni & 17 & 0 \\
\hline & Natimba & 27 & 0 \\
\hline & Peulh & 21 & 10 \\
\hline & Waama & 35 & 0 \\
\hline \multirow{2}{*}{ Gender } & Women & 68 & 150 \\
\hline & Men & 170 & 283 \\
\hline \multirow{3}{*}{ Age category } & Adult & 85 & 146 \\
\hline & Young & 129 & 228 \\
\hline & older & 24 & 59 \\
\hline \multirow{3}{*}{ Socio-professional groups } & Farmer & 212 & 401 \\
\hline & Breeder & 16 & 26 \\
\hline & Other & 10 & 6 \\
\hline
\end{tabular}

$(\mathrm{n}=689)$ 
Table 3 : Ecosystem services according to MA and repertory by Swinton and Zhang (2005).

\begin{tabular}{lll}
\hline Provisioning & Regulating and Supporting & \multicolumn{1}{c}{ Cultural } \\
\hline - Livestock Feed & $\bullet$ Pollination & $\bullet$ Education and \\
- Livestock & $\bullet$ Regulation of air quality & knowledge systems \\
- Building & - Erosion regulation & $\bullet$ Aesthetic values \\
- Crops & - Climate regulation & $\bullet$ Spiritual values \\
- Fuel & - Water purification & $\bullet$ Cultural practices \\
- Wild foods (plants et animal) & - Waste treatment & $\bullet$ Recreation \\
- Ornamental resources & - Natural hazard regulation & $\bullet$ Cultural heritage \\
- Plant-derived medicines & - Nutrient cycling & $\bullet$ Sense of place \\
- Fresh water & - Noise buffering & $\bullet$ Ecotourism \\
- Aqua-cultural fish & - Soil formation & \\
\hline
\end{tabular}

\section{RESULTS}

\section{Local perception of ecosystem services provided by forest ecosystems}

The results showed that the number of ES mentioned is not significantly linked to gender $(\mathrm{x} 2=3.1607$, dof $=2, \mathrm{p}=0.2059)$, but is linked to the climate zone $(\mathrm{x} 2=10.679$, dof $=2, p=0.0048)$. In general, provisioning services were the most recognized by the local community $(81.8 \%)$ followed by cultural services $(62.5 \%)$, regulating, and supporting services (36.36\%). Respondents in the Sudanese zone recognized few services than those respondents in the Sudanese-Guinean zone (Figure 2d). The provisioning services well-known in the two zones relate to the supply of wild foods ( $96 \%$ in the SudanoGuinean zone and $85 \%$ in the Sudanian zone), wood-fuels or $95 \%$ in the Sudano-Guinean zone and $65 \%$ in the Sudanian zone and medicinal plants at $82.8 \%$ and $60 \%$ respectively in the Sudano-Guinean zone and the Sudanian zone (Figure 2a). The supply of ornamental resources (85\% against $32 \%)$ and lumber $(84 \%$ against $25 \%$ ) were the most mentioned in the Sudano-Guinean zone, unlike the Sudanian zone. The offer of these services meet very little the community' expectation.
Over $50 \%$ of respondents have claimed the offer of these ES does not meet their satisfaction. Despite the importance of these ES for social well-being, more than $80 \%$ of those surveyed acknowledged their decline over the past five years (Table 4).

The regulation and support services were very little perceived in the Sudanian zone (Figure 2b) except climate regulation $(20.28 \%)$. On the other hand, services related to climate regulation (85\%), air quality regulation $(62 \%)$, and natural hazard regulation (45\%) have been widely known in the SudanoGuinean zone (Figure 2b). The importance of soil formation has been widely recognized (more than $50 \%$ ) by the respondents who mentioning it (Figure 2b). The level of satisfaction depended on the type of ES (Table 4). The regulation of natural hazards and the climate does not at all satisfy more than $40 \%$ of the respondents, unlike soil formation (55.47\%). Although these regulating and supporting services do not satisfy the local community, the improvement in the supply of services over the past five years has been widely reported (over 50\%) (Table 4).

Regarding cultural services, the local community in the Sudanian zone (10\%) and in 
the Sudano-Guinean zone (48\%) perceived the spiritual value. Besides, services such as cultural value $(15 \%)$, recreation $(49 \%)$, and aesthetic value $(15 \%)$ were perceived in the Sudano-Guinean zone (Figure 2c). These services are very important for more than 50\% of the respondents, but their supply is not very satisfactory (Table 4). These cultural services are in decline according to more than $80 \%$ of the local community except for the spiritual value $(92.04 \%)$ which does not change (Table 4).

\section{Local perception according to socio-cultural group of ecosystem services}

The results of the PCA (Figures 3, 4, and 5) showed that the two axes respectively explained the total variances in the frequencies of the rate of provisioning services $(60.90 \%)$, regulating services, supporting $(90.04 \%)$ and cultural services (76.32\%). Regarding provisioning services, the first axis $(37.13 \%)$ relates that the supply of wood fuel $(\mathrm{r}=0.85)$, the crops $(r=0.84)$, medicinal plants $(r=0.93)$, are the most mentioned by the Natimba, the Bariba, the Kabiè, the Waama and the Ditamari social-cultural group. On the other hand, the supply of fodder $(\mathrm{r}=-0.34)$ and freshwater $(r=-0.27)$ are more perceived by the Biali and the Lokpa social-cultural group (Figure 1a). The second axis $(23.77 \%)$, shows that the provision of ornamental resources $(r=0.89)$ is more perceived by the Lokpa, Ditamari, Kabiè, Nateni and Boo ethnic groups while for the Foudou, Natimba and Peulh communities, it is the supply of fodder $(r=0.47)$.

For regulation and support services, the first axis (56.3\%) is significantly and positively correlated with the natural hazard regulation $(\mathrm{r}$ $=0.88)$, the regulation of air quality $(r=0.97)$, and climate regulation $(\mathrm{r}=0.90)$. These services are the most cited by the Bariba and the Idaatcha social-cultural group. The second axis $(23.3 \%)$ is significantly and positively correlated with soil formation $(\mathrm{r}=-0.96)$. Natimba and the other social-cultural groups (Figure 4) perceived this service.

It appears from the projection of cultural services that axis 1 (49.68\%) shows, that the Kabiè, Waama and Peulh conceive that the education and knowledge system $(r=0.71)$, recreation $(r=0.87)$ and the aesthetic value $(r$ $=0.83$ ) are forest cultural service. On-axis 2 (26.65\%), we found that for the Bariba the Nateni and the others, the forest has a particular and supernatural meaning. For the Kabiè, Waama, and Peulh ethnic groups, forests are more perceived as sites of education and knowledge of aesthetic value.

\section{Factors determining the perception of ecosystem services}

It appears that several socio-demographic and socio-economic factors influence the perception of the local community of each category of ES. The poverty index is significantly and negatively determinants in the perception of provisioning services and regulating and supporting services $(\mathrm{p}<0.05$, Table 5). The level of education was also a significant determinant in the perception of provisioning services, regulating and supporting services ( $\mathrm{p}<0.05$, Table 5). People from and above primary school perceived the provisioning, regulating and supporting services more significantly, unlike those with no education. Also, young people significantly less perceived regulating and supporting services compared to adults and the seniors ( $\mathrm{p}$ $<0.05$, Table 5). Furthermore, cultural services were the most significantly cited than adults and young people ( $\mathrm{p}<0.05$, Table 5). People who own tree plantations were more significantly aware of provisioning, regulating and supporting services than those without plantation ( $p<0.05$, Table 5). Let's note that gender did not influence the perception of the three categories of ES ( $p>0.05$, Table 5). 
(a)

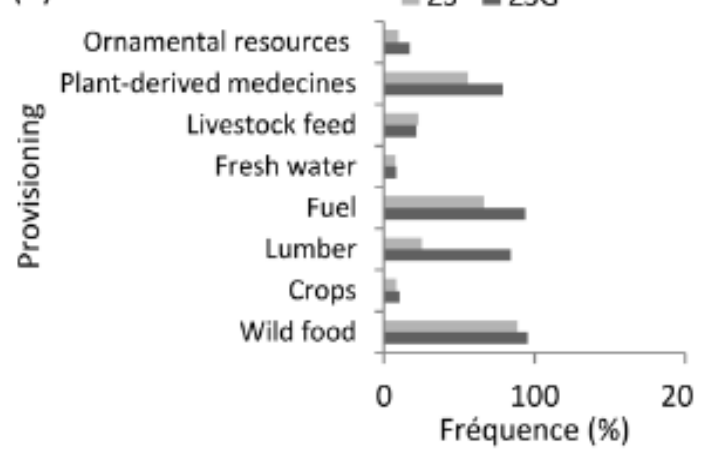

(c)

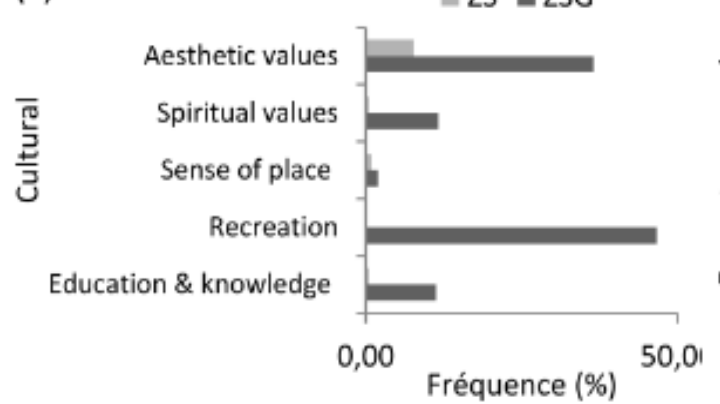

(b)

$=$ ZS $\quad$ ZSG

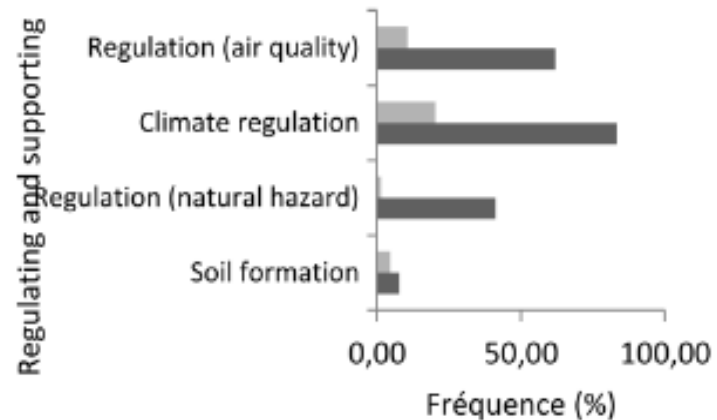

(d)

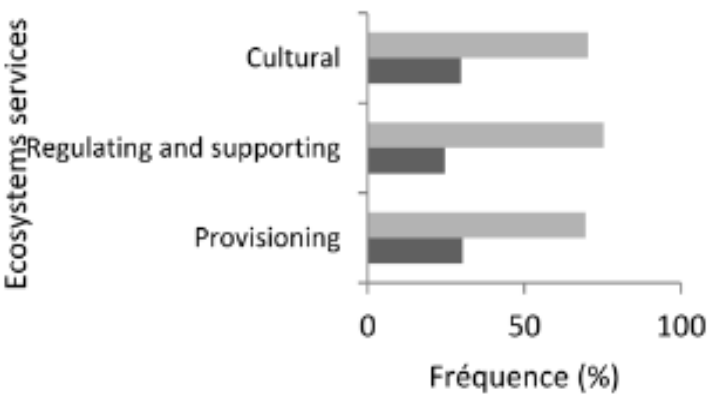

ZS= Sudanian Zone; ZSG= Sudanese-Guinean Zone

Figure 2: Identification rate of each Ecosystem Services groups according to ecological zone.

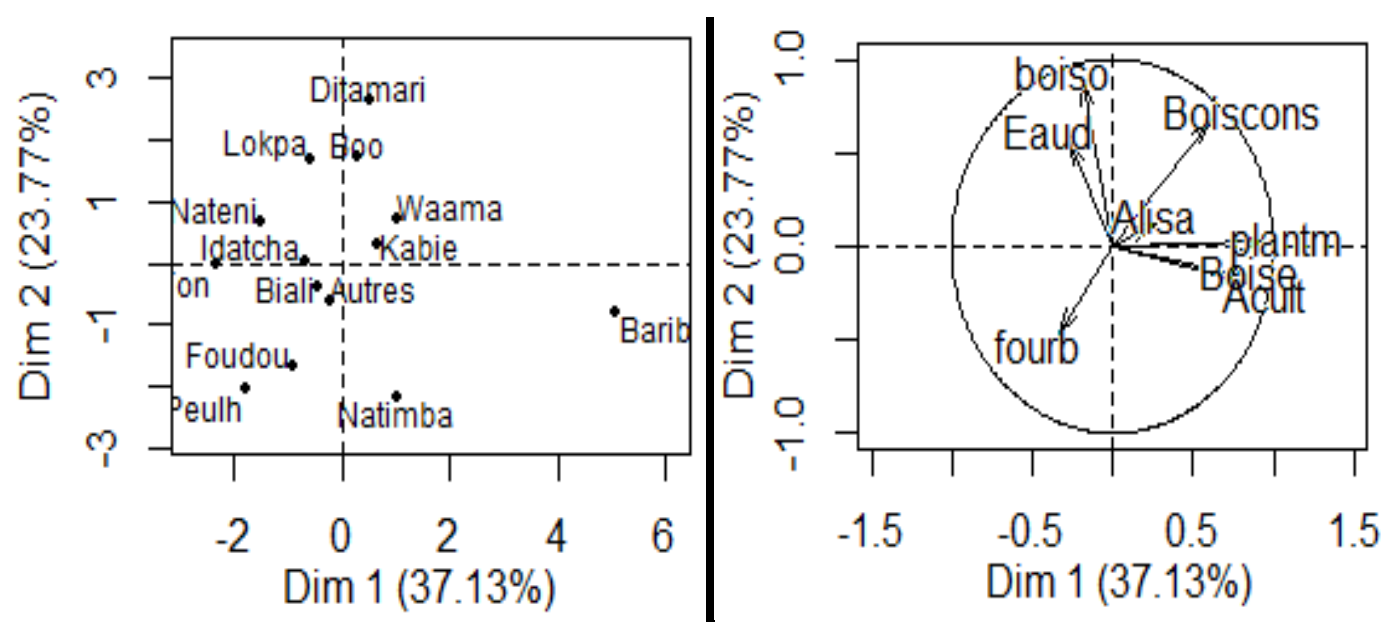

Eaud=Fresh water; boiso=Ornemental resources; Boiscons=Lumber; Alisa=wild food; fourb=Food

Figure 3: Projection of provisioning ecosystem services perception and sociocultural group in the principal space of PCA. 
F. C. AHONONGA et al. // Int. J. Biol. Chem. Sci. 14(5): 1716-1733, 2020

Table 4: Importance, satisfaction and trend of ecosystem services provided by the forest ecosystem.

\begin{tabular}{|c|c|c|c|c|c|c|c|c|c|}
\hline \multirow{2}{*}{ Perception } & \multicolumn{3}{|c|}{ Importance (\%) } & \multicolumn{3}{|c|}{ Satisfaction (\%) } & \multicolumn{3}{|c|}{ Trend (\%) } \\
\hline & None & Important & Very Important & Not satisfied & Very satified & Not very satisfied & Intact & Low & Improvement \\
\hline \multicolumn{10}{|l|}{ Provisioning services } \\
\hline Livestock feed & 0.65 & 33.50 & 65.86 & 29.06 & 9.58 & 61.36 & 2.91 & 83.98 & 13.11 \\
\hline Lumber & 0.86 & 40.54 & 58.60 & 29.38 & 5.21 & 65.41 & 1.01 & 88.79 & 10.20 \\
\hline Wild food & 1.72 & 32.50 & 65.77 & 30.19 & 5.77 & 64.04 & 1.92 & 88.89 & 9.20 \\
\hline Fresh water & 1.96 & 47.06 & 50.98 & 27.45 & 0.00 & 72.55 & 2.00 & 96.00 & 2.00 \\
\hline Feed & 0.00 & 30.00 & 70.00 & 30.00 & 11.67 & 58.33 & 5.17 & 84.48 & 10.34 \\
\hline Crops & 0.68 & 36.05 & 63.27 & 25.17 & 4.08 & 70.75 & 2.68 & 87.92 & 9.40 \\
\hline Plant-derived medicines & 0.46 & 27.19 & 72.35 & 28.87 & 6.47 & 64.67 & 2.75 & 90.83 & 6.19 \\
\hline Ornemental resources & 0.00 & 35.80 & 64.20 & 28.75 & 5.00 & 66.25 & 3.75 & 91.25 & 5.00 \\
\hline \multicolumn{10}{|c|}{ Regulating and supporting services } \\
\hline Soil formation & 1.56 & 25.00 & 73.44 & 33.59 & 10.94 & 55.47 & 11.90 & 9.52 & 78.57 \\
\hline Air quality regulation & 0.98 & 45.59 & 53.43 & 14.87 & 6.15 & 78.97 & 1.82 & 8.48 & 89.70 \\
\hline Natural hazard regulation & 0.00 & 24.35 & 75.65 & 56.25 & 2.68 & 41.07 & 1.85 & 97.22 & 0.93 \\
\hline Climate regulation & 0.32 & 34.42 & 65.26 & 49.16 & 3.03 & 47.81 & 1.02 & 95.59 & 3.39 \\
\hline \multicolumn{10}{|l|}{ Cultural services } \\
\hline Aesthetic value & 11.90 & 23.81 & 64.29 & 16.67 & 2.78 & 80.56 & 5.26 & 94.74 & 000 \\
\hline Knowledge system & 0.00 & 29.03 & 70.97 & 13.33 & 6.67 & 80.00 & 7.41 & 88.89 & 3.70 \\
\hline Recreation & 0.00 & 34.17 & 65.83 & 1.72 & 2.59 & 95.69 & 2.80 & 90.65 & 6.54 \\
\hline Sens of place & 0.00 & 25.00 & 75.00 & 25.00 & 12.50 & 62.50 & 12.50 & 87.50 & 0.00 \\
\hline Spiritual value & 3.88 & 28.68 & 67.44 & 33.33 & 3.70 & 62.97 & 92.04 & 0.88 & 6.72 \\
\hline
\end{tabular}



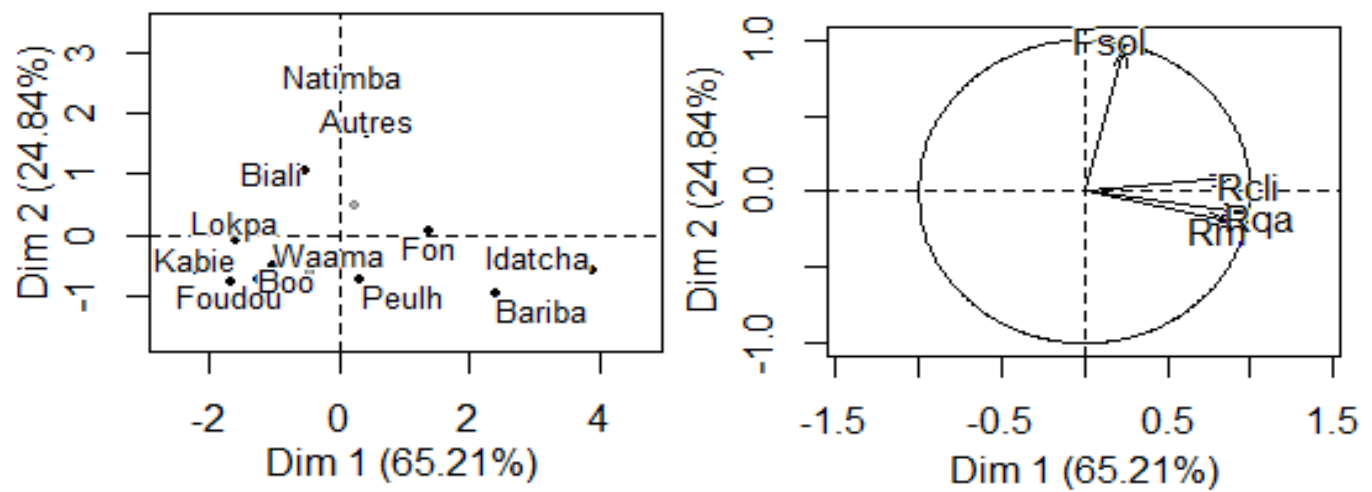

Fsol=Soil formation; Rclim=Climate Regulation; Rqa=Air quality Regulation; Rm=Normal hazard Regulation

Figure 4: Projection of regulating, supporting ecosystem services perception and sociocultural group in the principal space of PCA.
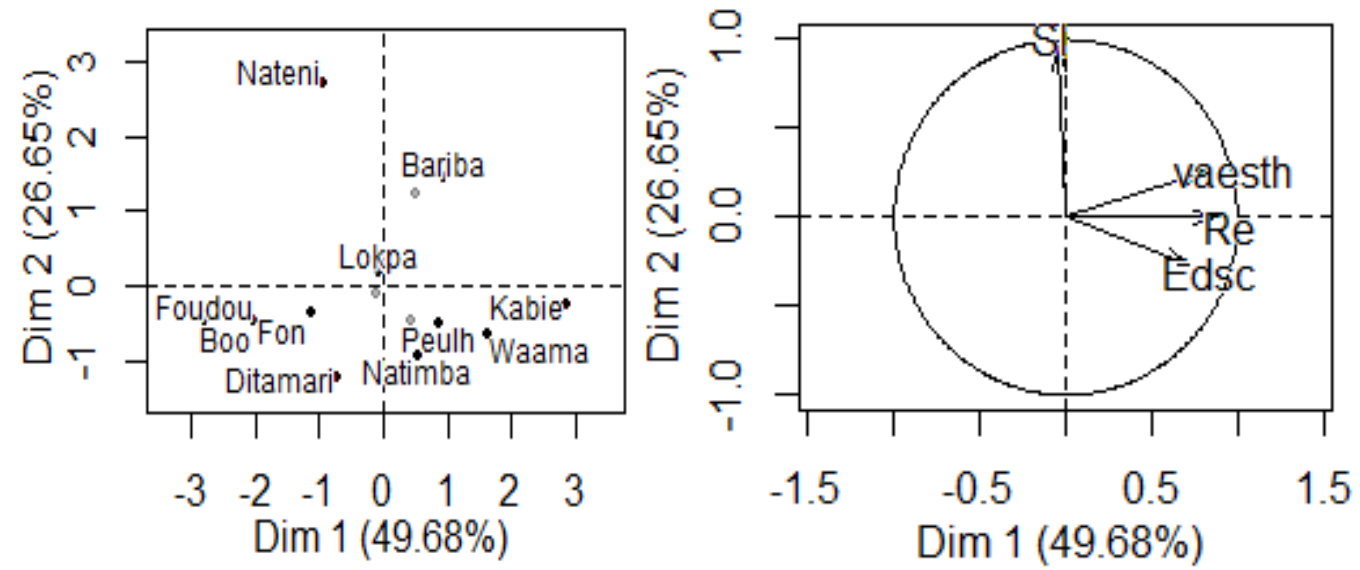

$\mathrm{Si}=$ Sens of Place; Vaesth=Esthetic Value $;$ Edsc=knowledge system

Figure 5: Projection of cultural ecosystem services perception and sociocultural group in the principal space of PCA.

Table 5: Determinants in the perception of Ecosystem Services of the Sudanese and SudaneseGuinean zones.

\begin{tabular}{|c|c|c|c|c|c|c|}
\hline \multirow[t]{2}{*}{ Services } & \multicolumn{2}{|c|}{ Provisioning } & \multicolumn{2}{|c|}{ Regulating and Supporting } & \multicolumn{2}{|c|}{ Cultural } \\
\hline & $\beta \pm \mathrm{SE}$ & $\mathrm{P}$ & $\beta \pm \mathrm{SE}$ & $\mathrm{P}$ & $\beta \pm \mathrm{SE}$ & $\mathrm{P}$ \\
\hline Constant & $1.46 \pm 0.21$ & $<0.001 * * *$ & $1.37 \pm 0.40$ & $<0.001 * * *$ & $-2.02 \pm 0.37$ & $<0.001 * * *$ \\
\hline Poverty & $-0.04 \pm 0.00$ & $<0.001 * * *$ & $-0.06 \pm 0.1$ & $<0.001 * * *$ & $0.00 \pm 0.01$ & 0.94 \\
\hline Young people & $-0.06 \pm 0.06$ & 0.33 & $-0.23 \pm 0.11$ & $0.039 *$ & $0.09 \pm 0.10$ & 0.41 \\
\hline Old & $0.03 \pm 0.08$ & 0.7 & $0.08 \pm 0.15$ & 0.57 & $0.63 \pm 0.14$ & $<0.001 * * *$ \\
\hline Elementary school & $0.13 \pm 0.06$ & $0.037 *$ & $0.25 \pm 0.12$ & $0.037 *$ & $-0.05 \pm 0.11$ & 0.64 \\
\hline Secondary school & $0.35 \pm 0.07$ & $<0.001 * * *$ & $0.29 \pm 0.13$ & $0.031 *$ & $-0.04 \pm 0.12$ & 0.74 \\
\hline University & $0.90 \pm 0.22$ & $<0.001 * * *$ & $1.42 \pm 0.43$ & $<0.001 * * *$ & $-0.04 \pm 0.38$ & 0.92 \\
\hline Gender & $-0.04 \pm 0.06$ & 0.53 & $-0.01 \pm 0.11$ & 0.93699 & $0.10 \pm 0.10$ & 0.34 \\
\hline Sudano-guinean & $-0.32 \pm 0.08$ & $<0.001 * * *$ & $-0.51 \pm 0.16$ & $<0.01 * *$ & $0.13 \pm 0.14$ & 0.36 \\
\hline Private Plantation [Yes] & $0.19 \pm 0.05$ & $<0.001 * * *$ & $0.25 \pm 0.10$ & $0.012 *$ & $-0.01 \pm 0.09$ & 0.9 \\
\hline
\end{tabular}




\section{DISCUSSION}

\section{Local perception of ecosystem services}

The local perception of ES varies within the local community. This suggests the complexity of the relationship between local perceptions and ES (Boafo et al., 2014). Provisioning services were more widely perceived, followed by cultural services, regulating, and supporting services. This result is explained by the tangible nature of provisioning services, unlike regulating and supporting services and cultural services (Lamarque et al., 2014; Martin-Lopez et al., 2012). Besides, provisioning services are directly involved in community well-being. This result corroborates those of Rodríguez et al. (2006), Muhamad et al. (2014), Ouko et al. (2018), Ahammad et al. (2019) and Gouwakinnou et al. (2019) and suggests that tangible services directly affect the community, unlike indirect services (Fisher et al., 2011; Ouko et al., 2018). It appears that the ES as a whole were more perceived in the Sudano-Guinean zone of Benin Republic. This result could be explained by the degraded state of forest ecosystems in the Sudanese domain as reported by several authors (Mama et al., 2013; Ousseni et al., 2016; Biaou et al., 2019). The poor knowledge of the ES by the local community in Sudanese zone is also explained by the differential level of development between the two ecological zones considered because in the Sudan-Guinean zone there are more developed localities than in the Sudanian zone. The most cited provisioning services in the Sudano-Guinean and Sudanian areas being the supply of wild food, wood energy, the supply of ornamental resources and medicinal plants, this result shows the dependence of the local community to close-ecosystem which provide services for their well-being, because they are important to them and satisfy the majority of the population. This supports the findings the rural community prioritizes substantial ecosystem benefits (Martín-López et al., 2012) whereas the urban community values only the more abstract services (Kroll et al., 2012). For example, collecting wild food can be an essential alternative source to enable people to maintain their livelihoods during lean periods (Ahammad et al., 2019). This is also the case with the supply of medicinal plants that help to cure illnesses (Gouwakinnou et al., 2011). Despite the tangible nature of these ES, their identification rate distinguishes sociocultural groups. This various use of forest ecosystems by socio-cultural groups suggests that the local community has a good knowledge of the material goods provided by closeecosystems and according to socio-cultural practices.

On the one hand, regulating and supporting services are lowly mentioned in the Sudanian zone except for climate regulation, though they are the main basis for the production of provisioning services. On the other hand, in addition to climate the community of the Sudano-Guinean zone mainly cited regulation, services related to air quality and the regulation of natural risks. This can be justified by the high concentration of environmental projects in the Sudano-Guinean zone than the Sudanian zone. This result corroborates those of Gouwakinnou et al. (2019) who showed the critical role of environmental education sessions and the intervention of projects within the local community. For Zhang et al. (2015), an environmental awareness can be explained by reforestation activities. Thus, this would explain the high number of mention of air quality service by the local community in the Sudano-Guinean area. Only a few sociocultural groups in the two climate zones also perceived the regulating and supporting services. Therefore, out of a dozen sociocultural groups, only four were able to cite regulating and supporting services. Services such as soil formation have not been known by the community, although soil quality is the most important element in most ES and forms the basis of primary production (TEEB, 2011). The poor mention of forest involvement in soil formation constitutes the reasons for land use without any sustainable land management initiative. This is worrying for sustainable land 
management because the population of the two climatic zones is mainly constituted of farmers. This result shows the importance of integrating a policy to sensitize people to strengthen the local perception of ES. This also confirms the relationship between the development level and the perception of indirect services. The under-developed localities, is concerned more with the improvement of its livelihood rather than with the factors of which depend on this livelihood. The low level of satisfaction with these services also shows the decline in forests, which modifies the ecological function of forest ecosystems. The actions of the population are more oriented towards activities that improve their income, for example, the establishment of private plantations dominated by Anacardium Occidental, Tectona grandis, and Gmelina arborea.

Cultural services, though intangible, contribute to the protection of biodiversity and therefore to the maintaining of ES. The services cited by the community related to the improvement of education and knowledge systems, spiritual value, and sense of the place. The perception of these services depended on socio-cultural groups. This suggests an intercultural difference in the services provided to each community (Vodouhê et al., 2009; Houehanou et al., 2011). The difference in citing cultural services within socio-cultural groups could be due to the influence of traditional knowledge regarding the forests and trees.

The local community also expressed the importance of cultural services. This result also shows the community's link to their forest. This cultural importance of forests should reflect the positive attitudes of the community towards the conservation of the natural forests of each region. The study by Fritz-Vietta, (2016) in Madagascar is a case where populations protect some of forests and trees for spiritual beliefs aimed at increasing wellbeing. Nowadays, we notice in the two study areas an uncontrolled exploitation of ecosystems as well as community forests dedicated to conservation. The regressive trend of these cultural services suggests the forests are losing their sacred aspect (Ryan et al., 2016) what impact conservation practices. According to Mama et al. (2013), the socioeconomic changes of human societies through the non-respect of ancestral nature conservation practices based on the development of myths and fear by the younger generation is the cause of the regression of forest ecosystems and therefore cultural services. Also, the change in religious beliefs and the decline of the influence of traditional chiefs don't facilitate to realize the importance of what is sacred (Byers et al., 2001; Sheridan, 2009) and ease the regression of spiritual and cultural values of forests not perceptible.

Taking into account the diversity of advantages offered by forest ecosystems and participatory decision-making can facilitate integrated forest management in types of land use (Ahammad et al., 2019). One of the objectives of Benin's forest policy is to improve forest cover without the necessary consideration of the socio-economic aspects that would contribute to the well-being of the population. This encourages managers to plant exotic species that are not very useful for the community. This approach to planting exotic species without taking into account the needful species for the community proves to be irrelevant because it does not contribute to biodiversity conservation and sustainability in supplying ES. Forest policy, focus on increasing of number of forest species, should take into account the aspirations and satisfaction of ES to increase the interest of populations in adapting to land use planning.

\section{Socio-economic drivers of ecosystem services}

We found that the poverty index is negatively correlated with the perception of provisioning services and regulating and supporting services. This seems surprising for provisioning services, because poor people are more interest in provisioning services that step in its livelihood. This suggests that apart from the living standard of the population, other 
factors must be taken into account. However, income can be decisive, because as shown by (Ahammad et al., 2019), the middle-income and wealthiest, are given the importance of provisioning services to improve their income. Regarding the correlation of regulating and supporting services with people on a low income could be explained by the non-tangible nature of this service, because very few sociocultural groups were able to cite these services. Also, its understanding requires mastery of ecological processes (Zhiyum et al., 2011).

Besides, people with at least a primary level of education perceived in a significant and positive way the provisioning, regulating and supporting services unlike the uneducated. This suggests that education has a positive effect on knowledge of regulating and supporting services and provisioning services. These results corroborate those of MartínLópez et al. (2012), Mensah et al. (2017), Ahammad et al. (2019), Gouwakinnou et al. (2019) and Moutouama et al. (2019) respectively in Bangladesh, Spain and South Africa and Benin which demonstrate that education could induce the attitude of people to support conservation policies and improve the attitude towards natural resources. Also, people age significantly influences the perception of the various ecosystem services except the supply service. Younger people less identified regulating and supporting services compared to adults and seniors. This result confirms (Moutouama et al., 2019) which explains the situation by the probable low experience of young people of disturbances and changes in agriculture. Young people with less experience of their environment probably do not have a reference base for perceiving the contribution of ecosystems to maintaining global balance. For Mensah et al., (2017), this is due to the accumulation of knowledge by older people over time. The seniors prefer cultural services linked to nature experiences while the young in urban areas tend to socialize (Riechers et al., 2018). Furthermore, cultural services were more widely known by the seniors than adults and young people. This shows the cultural conservationist behavior of elderly people, while the youth who is more attached to modern things. This confirms that the lack of information and experience can affect people perception of cultural services and also on the value they attribute to these (Mensah et al., 2017).

Gender shows no effect on people perception of ES. This seems surprising, because in Africa women are mostly involved in the ES collection (Mensah et al., 2017; Moutouama et al., 2019) respectively in South Africa and mountainous ecosystems in Benin. The crucial role of women in the household (Martin-Lopez et al., 2012) promotes awareness of the benefits and importance of direct environmental services (Allendorf and Yang, 2013). However, it seems obvious that ES that forest ecosystems provide today are all involved in the collection and exploitation of the different resources of the forest. Regarding regulating and supporting services, the issue of climate change, impacts, for example, all the ES that the community can benefit from forest ecosystems.

\section{Conclusion}

This study provides information for designing strategies and programs for better planning of local development linking with the objectives of biodiversity conservation. It shows how local perception, appreciation (importance, level of satisfaction, and tendencies of ES varied within the local communities. Provisioning services were ES category well perceived by local people even if their expectations are no longer meet due to a decline in supplying these services. The well knowledge of supply services unlike indirect services (regulating, supporting, and cultural) should incite to design an environmental education plan to improve knowledge of indirect services. Also, factors such as levels of education, age, socio-cultural group, and levels of prosperity highly influence the local perception of the various services. The integration of these factors would be a crucial point for policy and decision-making to 
process for ecosystem restoration as a source of the well-being of the population. The poverty index is a main factor in the perception of ES, it is appropriate to set up programs to improve livelihoods. Promoting income-generating activities around forest ecosystems could improve the living conditions of the local population. This would reduce the pressures on forest ecosystems.

\section{ACKNOWLEDGMENTS}

We express our sincere gratitude to the OSFACO for providing the SPOT images necessary for this study and to local communities for collaborating during this study.

\section{AUTHORS' CONTRIBUTIONS}

FCA, GNG and SSHB conceived the idea for the research project. FCA and SB collected and analyzed the data. FCA write the initial manuscript with contributions from GNG, SB and RCS All authors contributed critically to the discussion and edited the manuscript before submission.

\section{REFERENCES}

Ahammad R, Stacey N, Sunderland TCH, 2019. Use and perceived importance of forest ecosystem services in rural livelihoods of Chittagong Hill Tracts, Bangladesh. Ecosystem Services, 35: 8798.

DOI: https://doi.org/10.1016/j.ecoser.2018.11. 009

Allendorf TD, Yang J. 2013. The role of ecosystem services in park-people relationships The case of Gaoligongshan Nature Reserve in southwest. China. Biol. Conserv., 167: 187-193. DOI: https://doi.org/10.1016/j.biocon.2013.08. 013

Angelsen A, Jagger P, Babigumira R, Belcher B, Hogarth NJ, Bauch S, Börner J, SmithHall C, Wunder S. 2014. Environmental income and rural livelihoods: a globalcomparative analysis. World Dev., 64: 12-28.

DOI: https://doi.org/10.1016/j.worlddev.2014. 03.006

Avakoudjo J, Mama A, Toko I, Kindomihou V, Sinsin B. 2014. Dynamique de 1' occupation du sol dans le Parc National $\mathrm{du} \mathrm{W}$ et sa périphérie au nord-ouest du Bénin. Int. J. Biol. Chem. Sci., 8(6): 26082625.

DOI:

http://dx.doi.org/10.4314/ijbcs.v8i6.22

Asah ST, Guerry AD, Blahna DJ, Lawler JJ. 2014. Perception, acquisition and use of ecosystem services: human behavior, and ecosystem management and policy implications. Ecosyst. Serv., 10: 180-186. DOI:

https://doi.org/10.1016/j.ecoser.2014.08. 003

Belcher B, Achdiawan R, Dewi S. 2015. Forest-based livelihoods strategies conditioned by market remoteness and forest proximity in Jharkhand, India. World Dev., $\quad$ 66: 269-279. DOI: https://doi.org/10.1016/j.worlddev.2014. 08.023

Biaou S, Houeto F, Gouwakinnou G, Biaou HSS, Awessou B, Tovihessi S, Tete R. 2019. Dynamique spatio-temporelle de l'occupation du sol de la forêt classée de Ouénou-Bénou au Nord Bénin. In: Conférence OSFACO : Des Images Satellites Pour La Gestion Durable Des Territoires En Afrique. hal-02189367, Cotonou, Bénin, pp. 1-20.

Bidegain I, Cerda C, Catalán E, Tironi A, López-Santiago C. 2019. Social preferences for ecosystem services in a biodiversity hotspot in South America. $\begin{array}{lll}P L O S & \mathrm{ONE},\end{array}$ https://doi.org/10.1371/journal.pone.021 5715

Biga I, Amani A, Soumana I, Bachir M, Mahamane A. 2020. Dynamique spatiotemporelle de l' occupation des sols des communes de Torodi, Gothèye et Tagazar de la région de Tillabéry au Niger Spatiotemporal dynamics of the land use of Torodi , Gothèye and Tagazar township in the Tillabery region of Niger. Int. J. 
Biol. Chem. Sci., 14(3): 949-965. DOI: https://doi.org/10.4314/ijbcs.v14i3.24

Boafo Y, Osamu S, Takeuchi K. 2014. Provisioning ecosystem services in rural savanna landscapes of Northern Ghana: an assessment of supply, utilization and drivers of change. Journal of Disaster Research, 9: 501-515. DOI: https://doi.org/10.20965/jdr.2014.p0501

Byers B, Cunliffe R, Hudak A. 2001. Linking the conservation of culture and nature: a case study of sacred forests in Zimbabwe. Human Ecology, 29: 187-218. DOI: https://doi.org/10.1023/A:101101201424 0

Clerici N, Bodini A, Eva H, Grégoire J, Dulieu D, Paolinn C. 2007. Increased isolation of two Biosphere Reserves and surrounding protected areas (WAP ecological complex, West Africa). J Nat Conserv., 15: 26-40. DOI: https://doi.org/10.1016/j.jnc.2006.08.003

Costanza R, Fisher B, Mulder K, Liu S, Christopher T. 2007. Biodiversity and ecosystem services: A multi-scale empirical study of the relationship between species richness and net primary production. Ecological Economics, 61: 478-491.

DOI: https://doi.org/10.1016/j.ecolecon.2006.0 3.021

Cribari-Neto F, Zeileis A. 2010. Beta Regression in R. Journal of Statistical Software, 34: 1-24.

Cuni-Sanchez A, Pfeifer M, Marchant R, Calders K, Sorensen CL, Pompeu PV, Lewis SL. 2017. New insights on above ground biomass and forest attributes in tropical montane forests. For. Ecol. Manag., 399: 235-246. DOI: https://doi.org/10.1016/j.foreco.2017.05. 030

Dossou MKR. 2004. Rôle de la ressource forestière Blighia sapida (ackee ou faux acajou) dans 1 'économie des ménages du Nord-Ouest du Bénin Role of the Non Timber Forest Product Blighia sapida (ackee ) in household's economy in North-western Bénin, 33-41.

Fisher B, Bateman IJ, Turner RK. 2011. Valuing Ecosystem Services: Benefits, Values, Space and Time. DOI: https://doi.org/10.4337/9781781953693

Fritz-Vietta N. 2016. What can forest values tell us about human well-being? Insights from two biosphere reserves in Madagascar. Landscape Urban Plann, 147: 28-37. DOI https://doi.org/10.1016/j.landurbplan.201 5.11 .006

Gouwakinnou GN, Biaou S, Biaou SSH, Houeto OF. 2018. Effet des changements d'occupation des terres sur le flux du carbone: un exemple des forets classees de l'alibori-superieur et de ouenou-benou au benin, in: Images Satellitaires Pour Un Meilleur Aménagement Des Territoires et Une Gestion Durable de La Biodiversité. Campus universitaire d'Abomey-Calavi, Bénin, pp. 153-172.

Gouwakinnou GN, Biaou S, Vodouhe FG, Tovihessi MS, Awessou BK, Biaou HSS 2019. Local perceptions and factors determining ecosystem services identification around two forest reserves in Northern Benin. Journal of Ethnobiology and Ethnomedicine, 61: 112. DOI: https://doi.org/10.1186/s13002019-0343-y

Gouwakinnou, GN, Lykke AM, Assogbadjo AE, Sinsin B. 2011. Local knowledge, pattern and diversity of use of Sclerocarya birrea. Journal of Ethnobiology and Ethnomedicine, 7: 1-9. DOI: https://doi.org/10.1186/1746-4269-7-8

Houehanou T, Assogbadjo A, Glèlè Kakaï R, Houinato M, Sinsin B. 2011. Valuation of local preferred uses and traditional ecological knowledge in relation to three multipurpose tree species in Benin (West Africa). Forest Policy and Economics, 13: 554-562. DOI: https://doi.org/10.1016/j.forpol.2011.05. 013 
Houghton RA, Hackler JL. 2006. Emissions of carbon from land use change in subSaharan Africa. Journal of Geophysical Research: Biogeosciences, 111: 1-12. DOI:

https://doi.org/10.1029/2005JG000076

Hountondji YH. 2008. Dynamique environnementale en zones sahélienne et soudanienne de l'Afrique de l'Ouest: Analyse des modifications et évaluation de la dégradation du couvert végétal. Thèse de doctorat; Université de Liège. p.153

Ilboudo A, Soulama S, Hien E. 2020. Perceptions paysannes de la dégradation des ressources naturelles des bas-fonds en zone soudano-sahélienne: cas du sous bassin versant du Nakanbé-Dem au Burkina Faso Farmers ' Perceptions of lowland' $\mathrm{s}$ natural resources degradation in Sudano Sahelian area: case of Nakanbe-Dem Sub-Watershed in Burkina Faso. Int. J. Biol. Chem. Sci., 14(3): 883895.

DOI:

https://doi.org/10.4314/ijbcs.v14i3.19

Iniguez-gallardo V, Halasa Z, Briceño J. 2018.

People's Perceptions of Ecosystem Services Provided by Tropical Dry Forests: A Comparative Case Study in in Southern Ecuador and Briceño. Tropical Forests: $\quad 95-113 . \quad$ DOI: https://doi.org/10.5772/intechopen.7508 1

INSAE. 2016. Cahier des villages et quartiers de ville du departement du borgou (rgph4, 2013).

Kaboré SA, Schumann K, Hien M, Lykke AM, Hahn K, Nacro HB. 2015. Stratégies d'adaptation à la réduction des services écosystémiques: cas des potentialités de substitution de trois espèces forestières dans le Sud-Ouest du Burkina Faso. Int. J. Biol. Chem. Sci., 9(3): 1194-1208. DOI:

http://dx.doi.org/10.4314/ijbcs.v9i3.5

Kroll F, Müller F, Haase D, Fohrer N. 2012. Rural-urban gradient analysis of ecosystem services supply and demand dynamics. Land Use Policy, 29: 521-535. DOI:

https://doi.org/10.1016/j.landusepol.2011 .07 .008

Lamarque P, Meyfroidt P, Nettier B, Lavorel S. 2014. How ecosystem services knowledge and values influence farmers' decision-making. PLoS One, 9. DOI: https://doi.org/10.1371/journal.pone.010 7572

Mama A, Sinsin B, Cannière CDe, Bogaert J. 2013. Anthropisation et dynamique des paysages en zone soudanienne au nord du Bénin. Tropicultura, 31: 78-88.

Martin-Lopez B, Iniesta-Arandia I, GarciaLlorente M, Palomo I, Casado-Arzuaga I, Amo D, Gomez-Baggethun E, OterosRozas E, Palacios-Agundez I, Willaarts B, Gonzalez J, Santos-Martin F, Onaindia M, Lopez-Santiago C, Montes C. 2012. Uncovering ecosystem service bundles through social preferences. PLoS One, 7: e38970.

DOI: https://doi.org/10.1371/journal.pone.003 8970

MEA. 2005. Ecosystems and human wellbeing: Biodiversity Synthesis. Word Resources Institue. Washington. DOI: https://doi.org/10.1196/annals.1439.003

Mensah S, Veldtman R, Ephrem A, Ham C, Glèlè R, Seifert T. 2017. Ecosystem service importance and use vary with socio-environmental factors: A study from household-surveys in local communities of South Africa. Ecosystem Services, 23: $1-8 . \quad$ DOI: https://doi.org/10.1016/j.ecoser.2016.10. 018

Moutouama FT, Biaou SSH, Kyereh B, Asante WA, Natta AK. 2019. Factors shaping local people's perception of ecosystem services in the Atacora Chain of Mountains, a biodiversity hotspot in northern Benin. Journal of Ethnobiology and Ethnomedicine, 15: 1-10. DOI: https://doi.org/10.1186/s13002-0190317-0 
Muhamad D, Okubo S, Harashina K, Parikesit Gunawan BT, Akeuchi K. 2014. Living Close to Forests Enhances People's Perception of Ecosystem Services in a Forest-Agricultural Landscape of West Java, Indonesia. Ecosystem Services Journal, 8: 197-206. DOI: https://doi.org/10.1016/j.ecoser.2014.04. 003

Naidoo R, Weaver LC, Stuart-hill G, Tagg J. 2011. Effect of biodiversity on economic benefits from communal lands in Namibia. Journal of Applied Ecology, 48(2): $\quad 310-316 . \quad$ DOI: https://doi.org/10.1111/j.13652664.2010.01955.x

Ouko C, Mulwa R, Kibugi R, Owuor M, Zaehringer J, Oguge N. 2018. Community Perceptions of Ecosystem Services and the Management of Mt. Marsabit Forest in Northern Kenya. Environments, 5: 121. DOI: https://doi.org/10.3390/environments511 0121

Ousseni A, Gervais EC, Dramane I. 2016. Dynamique de l'occupation des terres et état de la flore et de la végétation dans le bassin supérieur de l'Alibori au Benin. Journal of Applied Biosciences, 108: 10531-10542.

Parrotta J, Yeo-chang Y, Camacho LD. 2016. Traditional knowledge for sustainable forest management and provision of ecosystem services. International Journal of Biodiversity Science. Ecosystem Services \& Management, 12: 1-4. DOI: https://doi.org/10.1080/21513732.2016.1 169580

Quintas-soriano C, Brandt JS, Running K, Baxter CV, Gibson DM, Narducci J. 2018. Social-ecological systems influence ecosystem service perception: a Programme on Ecosystem Change and Society (PECS) analysis. Ecology and Society, 23(3): 3. DOI: https://doi.org/10.5751/ES-10226230303
R Core Team. 2018. R: A Language and Environment for Statistical Computing.

Riechers M, Barkmann J, Tscharntke T. 2018. Diverging perceptions ecosystem services provided by urban green. Landsc. Urban Plan., 175: 161-168. DOI:

https://doi.org/10.1016/j.landurbplan.201 8.03.017

Rodríguez PJ, Beard TD, Bennett EM, Cumming GS, Cork S, Agard J, Dobson AP, Peterson G.D. 2006. Trade-offs across Space, Time, and Ecosystem Services. Ecology and Society, 11: 28. http://www.ecologyandsociety.org/vol11 /iss 1/art28/

Rodríguez-echeverry J, Echeverría C, Oyarzún C, Morales L. 2018. Impact of land-use change on biodiversity and ecosystem services in the Chilean temperate forests. Landscape Ecology, 33: 439-453. DOI: https://doi.org/10.1007/s10980-0180612-5

Ryan CM, Pritchard R, Mcnicol I, Owen M, Fisher JA, Lehmann C, Ryan CM. 2016. Ecosystem services from southern African woodlands and their future under global change. Phil. Trans. R. Soc. B, 371: 20150312 : 1-16. DOI: http://dx.doi.org/10.1098/rstb.2015.0312

Sambiéni K, Toyi M, Mama A. 2015. Perception paysanne sur la fragmentation du paysage de la Forêt classée de l'Ouémé Supérieur au nord du Bénin. [VertigO] La revue électronique en sciences de l'environnement, 15: 2. DOI: https://doi.org/10.4000/vertigo.16477

Scholte SSK, van Teeffelen AJA, Verburg PH. 2015. Integrating socio-cultural perspectives into ecosystem service valuation: A review of concepts and methods. Ecol. Econ., 114: 67-78. DOI: https://doi.org/10.1016/j.ecolecon.2015.0 3.007

Sheng H, Zhou P, Zhang Y, Kuzyakov Y, Zhou Q, Ge T, Wang C. 2015. Loss of labile organic carbon from subsoil due to landuse changes insubtropical China. Soil 
Biology and Biochemistry, 88. DOI: https://doi.org/10.1016/j.soilbio.2015.05. 015

Sheridan M. 2009. The environmental and social history of African sacred groves: a Tanzanian case study. Afr Stud Rev, 52: 73-98. DOI: https://doi.org/10.1353/arw. 0.0149

Swinton SM, Zhang W. 2005. Rethinking Ecosystem Services from an Intermediate Product Perspective. selected Paper prepared for presentation at the Ame; Providence; Rhode Island 24-27.

TEEB. 2011. TEEB manual for cities: ecosystem services in urban management. Econ. Ecosyst. Biodivers. Available at: www.teebweb.org

TEEB, 2010. The Economics of Ecosystems and Biodiversity Ecological [WWW Document]. Economic Foundations. London and Washington. URL http://www.teebweb.org/our-

publications/teeb-study-reports/, From: $\% 0 A E c o l o g i c a l-a n d-e c o n o m i c-$

foundations/

Urgenson LS, Prozesky HE, Esler KJ. 2013. Stakeholder Perceptions of an Ecosystem Services Approach to Clearing Invasive Alien Plants on Private Land. Ecology and Society, 18: 26. DOI: http://dx.doi.org/10.5751/ES-05259180126

Vodouhê FG, Coulibaly O, Adégbidi A, Sinsin B. 2010. Community perception of biodiversity conservation within protected areas in Benin. Forest Policy and Economics, 12: 505-512. DOI: https://doi.org/10.1016/j.forpol.2010.06. 008

Vodouhê GF, Coulibaly O, Greene C, Sinsin B. 2009. Estimating local values of nontimber forest products to Pendjari biosphere reserve dwellers in Benin. Economic Botany, 63: 397-412.
Wardle D, Zackrisson O. 2005. Effects of species and function group loss on island ecosystem properties. Nature, 435: 806810.

DOI: https://doi.org/10.1038/nature03611

Wilson MC, Richard XC, Didham RK, Ding P, Holt RD, Holyoak M, Hu G, Hughes AC, Jiang L, Laurance WF, Liu J, Pimm SL, Robinson SK, Russo SE. 2016. Habitat fragmentation and biodiversity conservation: key findings and future challenges Habitat fragmentation and biodiversity conservation: key findings and future challenges. Landscape Ecology, 31: 219-227. DOI: https://doi.org/10.1007/s10980-0150312-3

Yang YCE, Passarelli S, Lovell RJ, Ringler C. 2018. Gendered perspectives of ecosystem services: A systematic review. Ecosystem Services, 31: 58-67. DOI: https://doi.org/10.1016/j.ecoser.2018.03. 015

Zhang W, Kato E, Bhandary P, Nkonya EM, Ibrahim HI, Agbonlahor MU, Ibrahim HY. 2015. Communities' perceptions and knowledge of ecosystem services: Evidence from rural communities in Nigeria. Ecosystem Services, 22: 56. DOI: https://doi.org/10.1016/j.ecoser.2016.10. 011

Zhiyum O, Yu J, Tongqian Z, Hua Z. 2011. Ecosystem Regulating Services and Their Valuation of Hainan Island, China. Journal of Resources and Ecology, 2: 132-140.

DOI: https://doi.org/10.3969/j.issn.1674764x.2011.02.005. 